\title{
Review of precision rice hill-drop drilling technology and machine for paddy
}

\author{
Minghua Zhang ${ }^{1}$, Zaiman Wang ${ }^{1,2^{*}}$, Xiwen Luo ${ }^{1,2}$, Ying Zang ${ }^{1,2}$, Wenwu Yang ${ }^{1,2}$, \\ He Xing ${ }^{1}$, Baolong Wang ${ }^{1}$, Yizheng Dai ${ }^{1}$ \\ (1. Key Laboratory of Key Technology on Agricultural Machine and Equipment, Ministry of Education, \\ South China Agricultural University, Guangzhou 510642, China; \\ 2. Southern Regional Collaborative Innovation Center for Grain and Oil Crops in China, Changsha 410128, China)
}

\begin{abstract}
Mechanized rice direct seeding is a cost-effective and efficient approach for rice cultivation. Recently, the use of rice direct seeding has been increasing rapidly owing to rural labour shortages and continuous increases in agricultural production costs. This article reviews the research and application progress of mechanized rice direct seeding including direct seeding technologies, precision rice seeding, precision rice seed-metering devices, key supporting agronomy technologies for mechanized rice direct seeding. South China Agricultural University developed precision rice hill-drop drilling (PRHDD) with synchronous furrowing and ridging technology and series machines for paddy that affords remarkable advantages in terms of saving time and labour, higher yield, and higher efficiency. In this approach, pre-germinated seeds are uniformly hill-dropped in the expected positions in puddled soil. It significantly improved the crop growth population and effectively solved the problems of high frequency of disease and pests caused by the irregular distribution of rice seeds with manual broadcasting, and generally reduces seed usage and increases the yield. Therefore, this technology has broad application prospects and great potential for promoting the development of mechanized rice direct seeding in China.
\end{abstract}

Keywords: rice, precision rice seeder, hill-drop drilling for paddy rice, mechanical direct seeding

DOI: $10.25165 /$ j.ijabe.20181103.4249

Citation: Zhang M H, Wang Z M, Luo X W, Zang Y, Yang W W, Xing H, et al. Review of precision rice hill-drop drilling technology and machine for paddy. Int J Agric \& Biol Eng, 2018; 11(3): 1-11.

\section{Introduction}

Rice is an important staple food crop in the world. Its cultivated area worldwide is 160 million $\mathrm{hm}^{2}$, and this accounts for $22.3 \%$ of the total crop planting area. The gross product of rice is 741 million $\mathrm{t}$, and this accounts for up to $26.0 \%$ of global grain output $^{[1]}$ (FAO, 2017). Rice clearly plays an indispensable role in global food security. At present, global grain and food security are being greatly affected by many factors such as population, arable land, climate, and resources. Therefore, it is important to achieve good quality, high yield, improved efficiency, and sustainability of rice production and to accelerate rice industrialization to ensure long-term food security.

Received date: $2018-03-21 \quad$ Accepted date: 2018-05-08

Biographies: Minghua Zhang, Post-doctor, research interests: rice planting mechanization, agricultural mechanization, precision agriculture, Email: zhangminghuascau@163.com; Xiwen Luo, Professor, research interests: agricultural mechanization, agricultural machinery navigation, agricultural aviation, precision agriculture, intelligent agricultural equipment, Email: xwluo@scau.edu.cn; Ying Zang, Professor, research interests: agricultural mechanization, rice planting mechanization, agricultural aviation. Email: yingzang@scau.edu.cn; Wenwu Yang, Senior experimentalist, research interests: rice planting mechanization, agricultural mechanization, precision agriculture, Email: yangwenwu@scau.edu.cn; He Xing, PhD candidate, research interests: rice planting mechanization, Email: 675974347@qq.com; Baolong Wang, PhD candidate, research interests: rice planting mechanization, Email: 1531203262@qq.com; Yizheng Dai, PhD candidate, research interests: rice planting mechanization, Email: nc_vip@163.com;

*Corresponding author: Zaiman Wang, Associate researcher, research interests: rice planting mechanization, agricultural mechanization, precision agriculture. Email: wangzaiman@scau.edu.cn.
Mechanization is crucial for improving rice production. Among all steps in rice production, planting is the most complex, labour-intensive, and difficult to mechanize, and it greatly influences the production quality and final output of rice. At present, rice planting mechanization remains underdeveloped in China with an average level of only $44.45 \%$; this is lower than that of other food crops and even that of rice ploughing and harvesting itself.

Owing to rural labour transfer to cities $^{[2,3]}$, changing land transfer policies, and high costs, the growth rate of mechanical transplanting is decreasing. Rice direct seeding has been a less labour-intensive, high-efficiency, and simple method to cultivate rice. There are three main rice direct seeding methods ${ }^{[3,4]}$ : rice dry direct seeding (RDDS), in which dry seeds are sown in dry soil to depths of $1-3 \mathrm{~cm}$ before irrigation ${ }^{[5-7]}$; rice water direct seeding in which seeds are sown into standing water on ploughed dry land ${ }^{[8-10]}$; and rice wet direct seeding (RWDS), in which pre-germinated seeds are sown in wet puddled-precipitated-drained soils ${ }^{[11-13]}$.

Comparing with transplanting, rice direct seeding saves water $^{[14-19]}$ and reduces greenhouse gas (GHG) emissions ${ }^{[20-23]}$. Therefore, rice direct seeding mechanization is one of the most simple, effective, and sustainable ways to cope with labour shortages and high production costs ${ }^{[24-32]}$.

South China Agricultural University developed a precision rice hill-drop drilling (PRHDD) technology with synchronous furrowing and ridging for wet paddy. In this approach, pre-germinated seeds are uniformly hill-dropped in the expected positions in puddled soil. It significantly improves the crop growth population and effectively solves the problems of high frequency of disease and pests caused by the irregular distribution 
of rice seeds with manual broadcasting, and generally reduces seed usage and increases yield ${ }^{[33,34]}$. Therefore, PRHDD has become an important development direction for mechanized rice direct seeding in China.

This study aims to analyse the research progress and application status of PRHDD technology and machinery with synchronous furrowing and ridging as well as key related agronomic techniques to provide references for the promotion and application of PRHDD technology.

\section{Status of mechanized rice direct seeding}

\subsection{Worldwide status of mechanized rice direct seeding}

USA has the largest rice planting area among Euro-American countries with 1253 thousand $\mathrm{hm}^{2}$ and the yield of $8 \mathrm{t} / \mathrm{hm}^{2}$ in 2016 . The main rice planting areas are in the Mississippi River, Arkansas, and California, with Arkansas alone accounting for around half of the total planting area in $\mathrm{USA}^{[35]}$. The two main rice planting methods used in USA are aerial seed planting (20\%) and mechanical drilling (80\%).

Italy has the largest rice planting area in Europe with 234 thousand $\mathrm{hm}^{2}$ and the yield of $6.7 \mathrm{t} / \mathrm{hm}^{2[1]}$. The main rice planting areas are Pavia, Vercelli, and Novara in northern Italy ${ }^{[36,37]}$. The rice planting area in Italy is one-third of the total rice planting area in Europe (665 thousand $\mathrm{hm}^{2}$ ). Vercelli produces 33\% of Italy's rice yield, and it uses the most advanced rice production technologies in Italy ${ }^{[38]}$. Since the 1960 s, Italy has shifted from transplanting to mechanized RDDS ${ }^{[39]}$.

In Australia the rice planting area has decreased significantly from 113 thousand $\mathrm{hm}^{2}$ in 2013 to only 27 thousand $\mathrm{hm}^{2}$ in $2016^{[1]}$. However, Australia has the world's highest mean rice yield at 10 $\mathrm{t} / \mathrm{hm}^{2}$. Australia mainly uses mechanized rice planting methods such as RWDS and RDDS ${ }^{[36]}$.

In Japan, rice is the main food crop, and its planting area accounts for more than $80 \%$ of the total food crop planting area ${ }^{[1]}$. During the 1960s and 1970s, many studies focused on rice direct seeding technology, and the direct seeding area reached 55 thousand $\mathrm{hm}^{2}$. Mechanical transplanting is used for planting $99 \%$ of rice ${ }^{[40]}$, with the growing maturity of the technology of rice transplanter. By the end of the $20^{\text {th }}$ century, with increasing labour shortages and production costs, the direct seeding area increased from 8.9 thousand $\mathrm{hm}^{2}$ in 2000 to 27 thousand $\mathrm{hm}^{2}$ in $2014^{[41]}$. The mechanized direct seeding technologies used include RDDS, water direct seeding, and RWDS ${ }^{[42-45]}$.

In Korea, rice is the most important food crop too. Since 2012, the rice planting area has been decreasing, reaching 779 thousand $\mathrm{hm}^{2}$ in 2016 , although the total grain yield has remained stable at 5.6 million $\mathrm{t}^{[1]}$. In the $1970 \mathrm{~s}$, South Korea introduced mechanical transplanting technology from Japan and rapidly increased rice planting. With rapid urbanization, rural labour has largely transferred, and therefore, the direct seeding area has been increasing. In the 1990s, researchers began studying mechanized direct seeding technique ${ }^{[46]}$. Thus far, Korea has mainly used RWDS, followed by RDDS and water direct seeding (aerial seed planting ${ }^{[47]}$

In India, the rice planting area was 43 million $\mathrm{hm}^{2}$ in 2016, being around 1.3 times as much as that in China and the highest in the world. However, its total grain yield was 160 million $\mathrm{t}$, being around three-fourths of that of China.

The reason why these developed Euro-American countries can produce high yield of rice, is not only relating to rice varieties and soil climatic conditions, but also high precision direct seeding technology. The mechanization of rice production level of most Asian countries is far behind the developed countries. Meanwhile, they produce less rice. Obviously, rice yield is positively correlated with mechanization level. Therefore, it is urgent to improve the mechanization level of rice production.

\subsection{Mechanized rice direct seeding in China}

China is one of the major rice-producing countries with the largest total rice yield (27\%) in the world. In 2014, 2015, and 2016 , its rice yields were 207, 208, and 210 million t, accounting for $37.0 \%, 36.4 \%$, and $36.0 \%$ of China's total grain crop yield and $27.8 \%, 28.1 \%$, and $28.2 \%$ of the world's total rice yield, respectively ${ }^{[1]}$ China's rice planting mechanization level currently exceeds $40 \%$. China's "Thirteenth Five-Year Plan" has proposed to increase rice-planting mechanization level to $60 \%$.

Historical records shows that China has a long history of using rice direct seeding, with technology for the same being developed during the Han Dynasty. The Chinese government has introduced rice seedling mechanized transplanting methods over the years owing to their relatively stable total rice yield. However, high cost and labor intensity were also attached. Declining rural labour forces and increasing labour costs have increased the growth of mechanical direct seeding in suitable areas rapidly. Therefore, mechanical direct seeding shows high potential for achieving $20 \%$ growth of rice planting mechanization level in five years ${ }^{[48]}$.

China has a large rice planting area $\left(20^{\circ} \mathrm{N}-50^{\circ} \mathrm{N}, 75^{\circ} \mathrm{E}-150^{\circ} \mathrm{E}\right)$ and the climate and soil vary greatly. Therefore, there are regional distribution differences between RDDS and RWDS. During the rice seeding season, RDDS is suitable in northern China (Xinjiang, Ningxia, etc.) where there is less rainwater. By contrast, RWDS is suitable in southern China where there are many spring rains owing to the monsoon climate ${ }^{[6]}$. Rice water direct seeding is not used commonly in Asia ${ }^{[49,50]}$. The pulp method is generally used in paddy fields ${ }^{[51]}$, where the flow of the water and mud layers is not conducive to rice rooting and seedling. Meanwhile, water direct seeding requires a large number of seeds to reduce the effect of uneven density produced by seed drift and therefore ensure adequate planting density ${ }^{[5]}$. Intensive agriculture and precision planting modes can increase the utilization and output of agricultural resources ${ }^{[52-55]}$. Therefore, the Euro-American aerial seed planting mode with water is not applicable from the perspective of China's basic national conditions with fewer resources per capita.

The research team of South China Agricultural University invented PRHDD technology with synchronous furrowing and ridging to meet the agronomy requirements of different regions, rice cycles, and varieties to address the problems faced with manual broadcasting, field growth disorder, low group quality, and poor resistance.

PRHDD with synchronous furrowing and ridging opens water furrows and seed furrows in the field synchronously. Then, rice seeds are sowed into the seed furrow by hill-drop drilling to achieve hill-in-row growth and ridge planting (Figure 1). The soil on the seeding furrow wall will be backfilled to cover the seeds and increase the rice root penetration depth with the scouring of rainwater. This increases the soil redox potential, which is favourable for root growth and root structure improvement owing to less ridge flooding. The results showed that PRHDD reduced yellow roots by $20 \%$ and black roots by $13 \%$ and increased white roots by $33 \%$ compared to manual broadcasting. The water furrow between ridges provided water for rice growth without entire surface irrigation, thus reducing the irrigation water needed 
by more than $30 \%$. Rice is a group crop, and hill-drop drilling provides balanced space for its growth. Multigrain polygamy in the hills is conducive to top soil emergence, competition with each other, and high-yield group establishment.

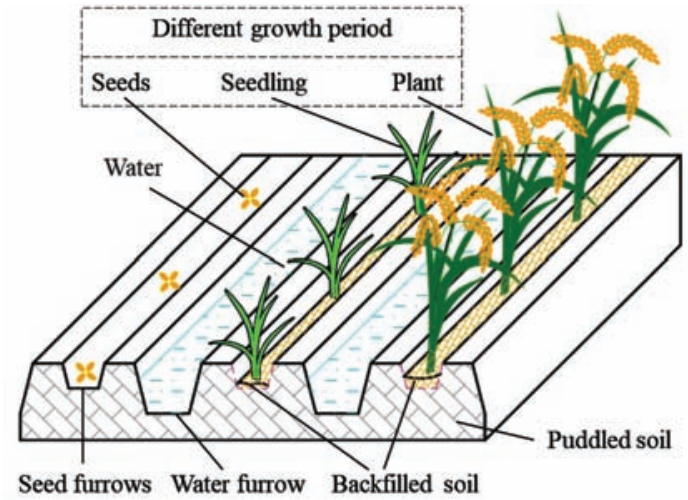

Figure 1 The principle of synchronous furrowing and ridging hill-drop drilling for wet paddy

\section{Review of precision rice metering devices}

The seed metering device is a key part of a direct seeding machine. Rice direct seeding machines have two main types of metering devices: mechanical and vacuum. Mechanical drillers equipped with grooved roller-type metering devices are widely used in developed countries such as USA, Australia, and European countries. This metering device is simple and cheap, and it is easy to adjust the sowing rate and adapt to high working speeds ${ }^{[56]}$. A spiral grooved metering device can improve the seed distribution uniformity in the sowed row $^{[57,58]}$. Amasone designed control seed wheels (Figure 2) with sowing rate adjustable from 1.5 to 400 $\mathrm{kg} / \mathrm{hm}^{2}$ and high precision ${ }^{[59]}$.

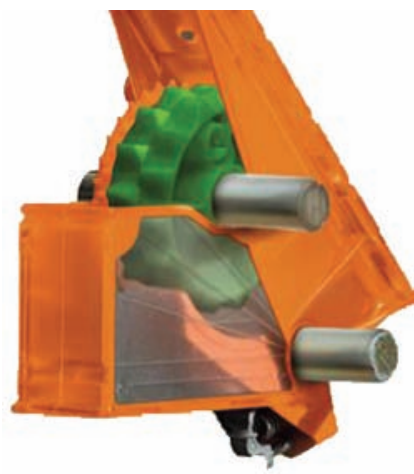

Figure 2 Schematic view of control seed wheels

A pneumatic metering system includes a large grooved roller, a fan, a pipeline, and one (or more) seed equator (s). Seeds dropped from a large grooved metering roll are mixed with the air flow generated by a fan, and the seeds are blown to the seed equator through the pipeline. Then, the seeds are sown in the opened seed furrow $^{[60]}$. A multi-in-one (multiple sowing pipes mounted on one seed equator) pneumatic metering system simplifies this mechanism, and it is mainly used in large wide seeders.

In Japan and Korea, grooved roller-type metering devices are most popularly used for direct seeding. Currently, direct seeding metering devices used for both row drilling and hill-drop drilling machines have been improved based on a roller-type metering device (Figure 4) designed by $\mathrm{Ryu}^{[56]}$ and Yoo et al. ${ }^{[61]}$. The sowing rate can be adjusted by adjusting the opening gap of the grooves on the roll surface. Togashi ${ }^{[62]}$ and Tasaka et al. ${ }^{[63]}$ studied a shooting gun metering device (Figure 5) in which a saw-tooth disc rotates at a certain speed and hits seeds dropped continuously from a pipe to accelerate them. The seeds are hill-dropped into the soil based on the time intervals at which adjacent saw-teeth hit the seeds. Experimental results showed that the hill-drop effect was the best when the saw-tooth disc diameter was $190 \mathrm{~mm}$, thickness was $20 \mathrm{~mm}$, number of teeth was 32, and material was elastic; gap regulation of saw-tooth disc and tube was 1-3 $\mathrm{mm}$; seed tube length was $190 \mathrm{~mm}$, diameter of long and short sides was $28-30 \mathrm{~mm}$ and $23-25 \mathrm{~mm}$, respectively; and angle $\theta$ was $10^{\circ}-15^{\circ}$.

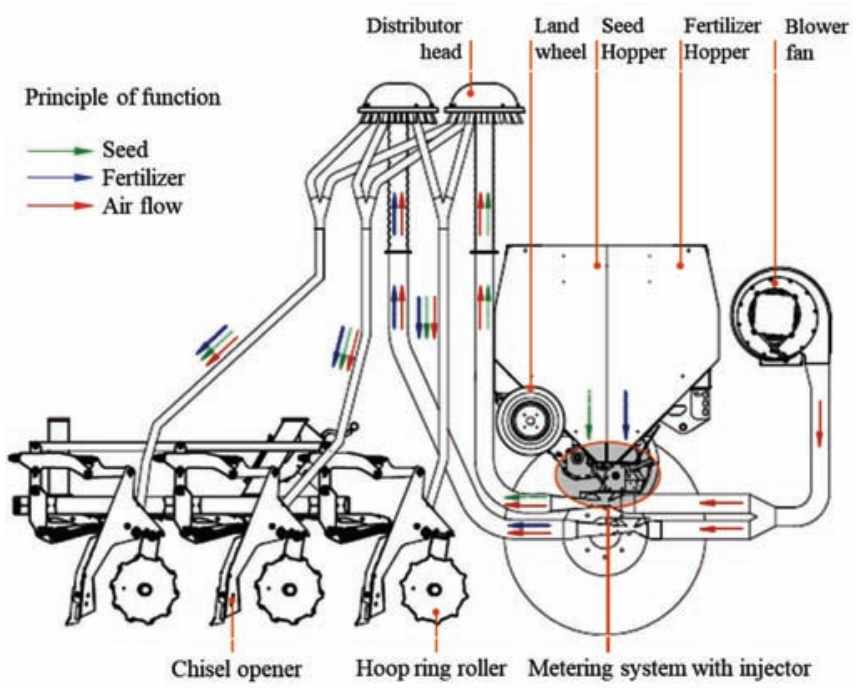

Figure 3 Schematic view of pneumatic metering system

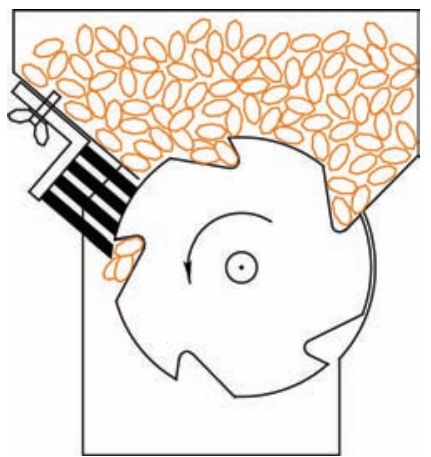

Figure 4 Schematic view of roller-type metering device

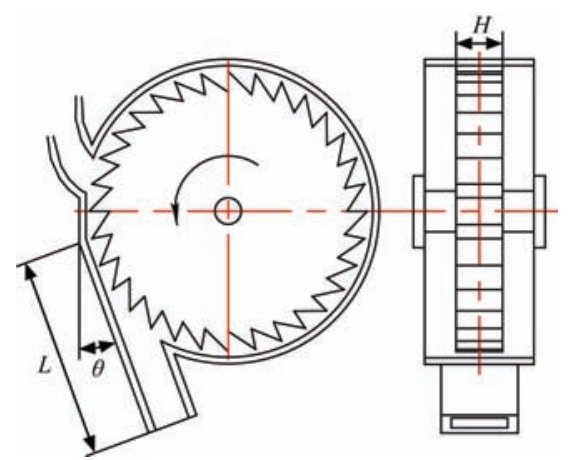

Figure 5 Schematic view of shooting gun metering device

In China, various seed metering devices have been developed to achieve precision rice direct seeding for different rice varieties. RDDS requires a higher sowing rate and working speed, as well as soil with low water content. Therefore, seeds bounce when they are dropped on the soil, making it very difficult to achieve hill-drop drilling without using any special devices. As a result, few existing metering devices are suitable for precision rice hill-drop drilling for dry land. 
Zhang et al. ${ }^{[64]}$ from Huazhong Agricultural University designed a pneumatic cylinder-type precision direct seed-metering device, shown in Figure 6. This device features a conical-shaped hole, multi-suction hole filling, flexible cord for gas-blowing of seeds, flexible guard seed banding, and gas blow prevention. CFD software was used to simulate the airflow field in different holes and experiments were conducted to determine the optimal parameters of the seed metering device. Bench test and field experiment results showed that the pneumatic cylinder-type precision direct seed-metering device can meet the fine sowing requirement of hybrid rice. Huazhong Agricultural University designed a double-chamber side-filling-type metering device with a curved brush seed protection apparatus ${ }^{[65]}$. They used single-chamber sowing for hybrid rice and double-chamber sowing for conventional rice. The structure of the seed disk diameter, number of holes, hole diameter, hole depth, hole position, seed brush, and anti-blocking device were determined through theoretical calculations and experiments.

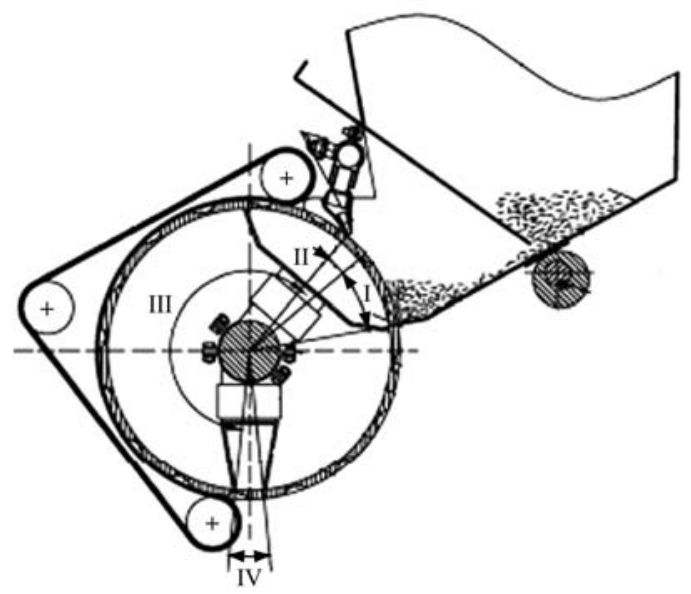

Figure 6 Structure diagram of pneumatic cylinder-type precision direct seed-metering device

The Xinjiang Production and Construction Corps (China) modified a duckbill membrane perforated cotton seed metering device, as shown in Figure $7^{[66]}$. The modified device filled seeds after it reached the planting zone, and the duckbill tapped into the soil. Then, the duckbill opened to release seeds. As the duckbill reaches a certain depth into the soil, seeds do not bounce, resulting in better seeding. However, the sowing rate and hill distance adjustment in this device were not convenient. Chen et al. ${ }^{[67]}$ developed a gas-suction seed metering device with a tape guide. This device synchronized the seeds and the seeder and enveloped seeds in the guide belt and guard plate formed in the cavity while the top of metering device transported seeds. Seeds fall freely when close to sowing location to complete seeding. Because the seed furrow is close to the seeding point, it can solve the problem of seed bouncing.

South China Agricultural University studied the interaction mechanism between the rice seed and the metering device from the viewpoint of wide planting area, large variety, and fine sowing requirement of rice. They determined the flow characteristics of different rice varieties as well as their corresponding filling mechanisms and seeding laws. They developed three types of PRHDD seeding devices for different regions, different varieties, and different sowing approaches of rice.

For sowing rate requirements of $30-75 \mathrm{~kg} / \mathrm{hm}^{2}$ of conventional and hybrid rice varieties, a combined hole-type metering device with adjustable sowing rate ${ }^{[68]}$ was developed, as shown in Figure 8.
This device used combination type-holes and a double-chamber filling mode with elastic follow-up protecting method. This improved the uniformity of rice seeding, reduced the rice damage rate to $0.2 \%$, and achieved sowing rate adjustment of 3-20 seeds per hill.
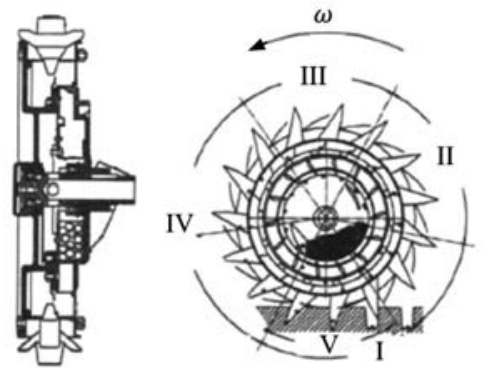

Note: I. Suction area; II. Cleaning area; III. Transport area; IV. Dropping area, V. Hill-drop area.

Figure 7 Schematic diagram of duckbill metering device configuration

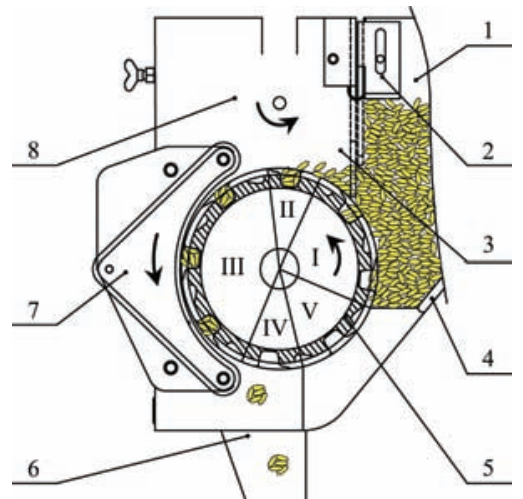

1. First filling place 2. Seeds flow adjusting device 3. Second filling place 4. Unload plate 5. Combined hole-type roll 6. Tube 7. Protecting device 8. Cleaning device.

I. Filling area II. Cleaning area III. Protecting area IV. Dropping area V. Transition area.

Figure 8 Structure diagram of combined hole-type metering device

For the sowing requirement of $15-30 \mathrm{~kg} / \mathrm{hm}^{2}$ for some hybrid and super-rice varieties, a vacuum vertical disc metering device was developed ${ }^{[69-71]}$, as shown in Figure 9. This device applied negative pressure sucking, seed introduction through guide teeth, and a stratified diversion mode. Airflow characteristics were used to carry and transport seeds and thus improve the adaptability of seeds, reduce the seed damage rate, and improve the sowing accuracy. Production test results showed that the vacuum disc metering device can adapt to various super hybrid rice varieties with $95 \%$ of $1-3$ seeds per hill and less than $2 \%$ missing rate.

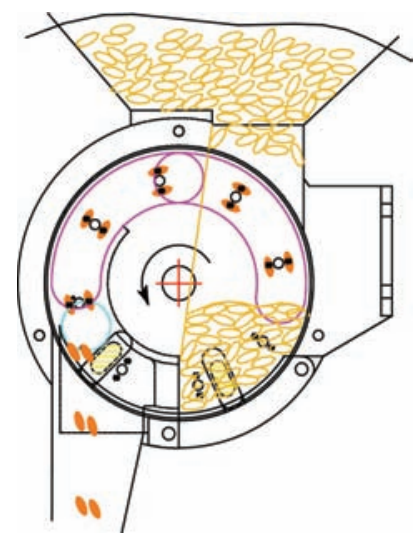

Figure 9 Configuration of vacuum vertical disc metering device 
Another vacuum drum metering device (Figure 10) was developed for direct seeding of $15-30 \mathrm{~kg} / \mathrm{hm}^{2}$. This device comprised inner and outer cylinders, a lateral sucking mechanism, and a guide tube. Different sowing rates were achieved through the control of the outer hole and the suction and discharge air pressure. The air flow and guide tube were adjustable so as to achieve $91.6 \%$ probability of placing $(2 \pm 1)$ seeds in each hole and only $2.7 \%$ probability of a hole being left empty.

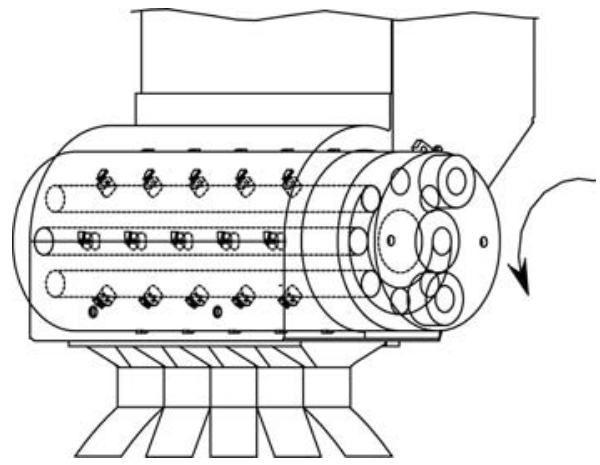

Figure 10 Configuration of vacuum drum metering device

\section{Application status of precision direct seeding machine}

4.1 Worldwide application of precision direct seeding machine

In Euro-American countries, mechanical (Figure 11a) and pneumatic (Figure 11b) direct seeding machine s are used for both rice and wheat drill seeding. Pneumatic direct seeding machine were used in air-drilling seeding. Mechanical direct seeding machine s show higher accuracy than Pneumatic direct seeding machine $s$ because they use a grooved roll or independent double-row gear metering device. The most well-known direct seeding machine manufacturers worldwide are Amasone in Germany, MaterMacc and Maschio Gaspardo in Italy, and John Deere in America. These manufactures have developed some mechanical and pneumatic seed drills with different structures and configurations for different applications.

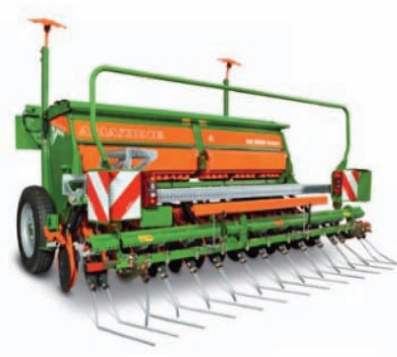

a. Mechanical seed drills

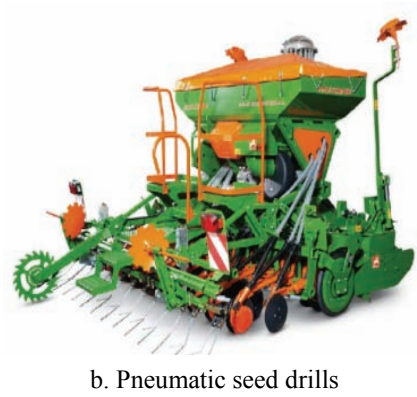

b. Pneumatic seed drills
Figure 11 Large area seed drills used in developed countries

Kajitani $^{[72]}$ from Japan has developed a no-tillage and RDDS with the working principle similar to that of a duckbill cotton seed metering device. It uses a puncher mounted on the periphery of a rotating disk to drill the seeds into the soil, and the seeding door is synchronously opened by the force from contact with the ground. Hill-drop drilling could be realized by releasing seeds and fertilizer into soil and covering the soil. Yashiro ${ }^{[73]}$ developed an RDDS with rotary tillage. After rotary tillage and crumbling of the soil, the furrower rotates automatically and creates a seed furrow. The seed-metering device sows seeds into the bottom of the furrow, then the furrows will be covered with soil when water floods.

Iseki and Yanmar have jointly developed an rice direct seeding machine with the chassis of a transplanter. This device could profile and open seed furrows synchronously and use a roller-type metering device to sow seeds on the paddy surface ${ }^{[74-77]}$. Chosa ${ }^{[78]}$ and Furuhata ${ }^{[79]}$ developed an air-assisted strip seeder. This seed-metering device has two rows of pipe. The device sends seeds into a tube, and the airflow generated by the rear fan is sent into different seeding tubes through the distributor to blow seeds through the injection port. As the metering nozzle is narrowed, the flow speed increases, and seeds are injected into the soil faster.

Kubota, Iseki, and Yanmar are the three largest Japanese agricultural machinery companies, and manufacture good-quality paddy field machines. Their rice transplanters are dominant in the Asian market. These companies develop rice direct seeding machines powered by a high-speed rice transplanter chassis (Figure 12). Furrowers are mounted at the bottom of the pontoons. The middle pontoon is used to sense the ground surface for profiling and to sow seeds into seed furrows. However, this type of seeder is only used in Japan currently.

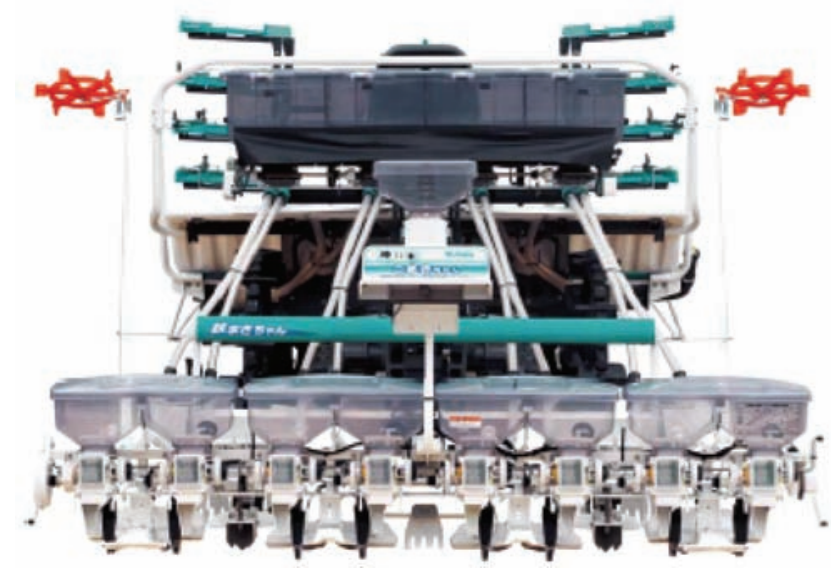

Figure 12 Precision direct seeding machine (Kubota)

Most of the rice planting machines and technology used in Korea are introduced from Japan. In response to the demands of direct seeding in both paddy fields and dryland, a new type of multifunctional rice direct seeding machine (Figure 13) was developed in Korea. This machine was powered by tractor. It used a spiral filling device to level the land and to eliminate wheel tracks. Rice seeds and fertilizers were sown into the seed furrows and fertilization furrows, respectively, and covered with soil. This seeder can be used in both wet puddled fields and dryland ${ }^{[80]}$.

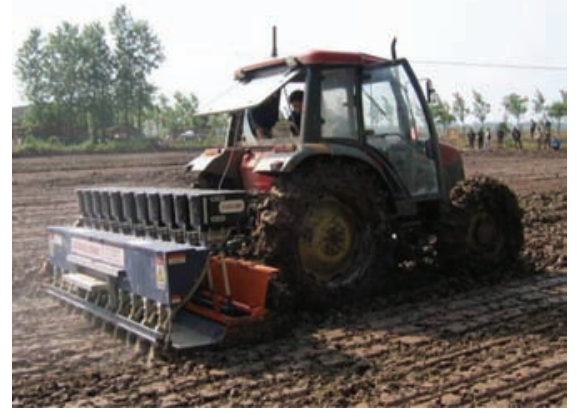

Figure 13 Multifunctional rice hill-drop drilling machine

\subsection{Application status of precision rice direct seeding machine in China}

Owing to rural labour shortages in China, the advantages of time-saving, labour-saving, and low labour intensity of rice direct seeding technologies are considered promising. Therefore, many studies have been investigating PRHDD in recent years. Various types of rice s have been developed and popularized.

Initial rice s included simple rice drillers such as the Shanghai 
Hujia 2BD series rice. It did not open the seed furrow, and seeds were directly sown onto the muddy surface with an outer sheave seeding device. In 2011, Nanjing Agricultural University developed a precision RPDDH machine ${ }^{[81]}$ with an intermittent-drive seeding mechanism to drive the horizontal disc-type seeding device. However, the seed number of each hill cannot be adjusted, and the sowing rate could only be adjusted by adjusting the hill spacing. Nanjing Institute of Agricultural Mechanization developed a 33-row pneumatic row-type rice with a folding frame with a working width of $8 \mathrm{~m}$ and working speed of $10 \mathrm{~km} / \mathrm{h}$ to meet the planting requirements of farms of various scales. Jiangsu Agricultural Machinery Extension Station developed a belt-type rice direct seeding with a furrower under the plastic baseplate. This device could only open a very shallow seed furrow, and therefore, it was not very useful for sowing. Anhui Agricultural University ${ }^{[82]}$ developed an rice direct seeding machine with an eight-way circular groove push and spoon wheel-type seed-metering device that was powered by a paddy rice transplanter. This machine could achieve ditching furrow and precise direct seeding synchronously, with 8 seeding rows, $250 \mathrm{~mm}$ row space, and hill spacing range of 100-240 mm. However, this machine had no profiling mechanism, and it required flat and compact soil before seeding.

At present, the most popular PRHDD machine in China is a synchronous furrowing and ridging PRHDD machine (Figure 14) developed by South China Agricultural University ${ }^{[83-85]}$. This machine can perform synchronized furrowing, ridging, and precise hill-drop drilling, and it has adjustable hill spacing, optional row spacing, and profiling operations.

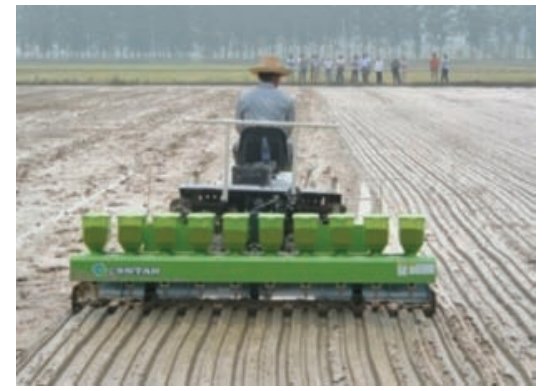

Figure 14 Structure diagram of precision rice hill-drop drilling machine

The PRHDD machine uses a transplanter chassis to provide power for moving and seeding. The hydraulic cylinder and lifting frame are installed on the back of the transplanter chassis. The slide board always clings to the mud surface owing to the effect of the altimetric and horizontal profiles. The seed and water furrows are formed as the machine moves forward. The seed-metering device is driven by a power transmission system, and it sows seeds into the seed furrows. The fenders on both sides prevent the influx of water and mud into the seeding are ${ }^{[86]}$.

Using PRHDD with synchronous furrowing and ridging technology, the rice can grow well in a well-formed orderly manner with good ventilation and light to improve the emergence rate of rice, lodging resistance ability of direct seeding rice, and yield and quality of rice ${ }^{[87]}$.

To meet the demands of different regions, South China Agricultural University developed a series of RWDS machines (Figure15).

1) The simplified PRHDD machine (Figure15a) is powered by a diesel engine, and it uses a hole-type seed-metering device to sow seeds into a seed furrow. However, owing to its low operating efficiency, this machine is mainly used only in small fields in hilly areas.

2) The PRHDD machine with synchronous side deep fertilizing (Figure 15b) opens fertilizer furrows in the middle of two seed furrows ${ }^{[88]}$. This fertilizer is applied to rice in two seed furrows, thus reducing the fertilizer cost and increasing the total yield of rice.

3) The PRHDD machine with synchronous spraying (Figure 15c) can spray herbicide or a liquid film synchronously with hill-drop drilling. The herbicide controls weeds in the early growth stage of rice, and the liquid film can reduce the influence of low temperature on seedling emergence.

4) The PRHDD machine with a vacuum vertical disc (Figure 15d) and drum (Figure 15e) can be applied to hybrid rice, especially super hybrid rice, with seeding rate of 1-3 seeds per hill $^{[89]}$.

5) The wide PRHDD machine powered by a wheeled tractor (Figure 15f) uses the hydraulic folding method to facilitate transferring on the road, and it uses a spiral mechanism to eliminate wheel tracks ${ }^{[90]}$. It can synchronously perform profiling, furrowing, and ridging. It has 21 seeding rows with working width of $4.5 \mathrm{~m}$; this significantly increases its working efficiency and enables application to large-scale farms.

Table 1 shows the main specifications of different types of PRHDD machines currently used in China.

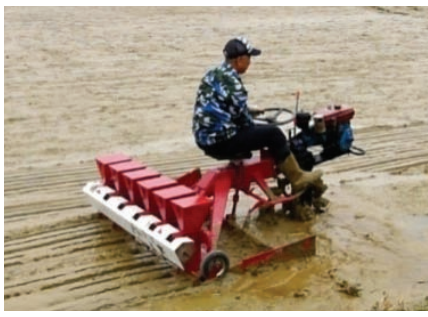

a. Simplified PRHDD machine

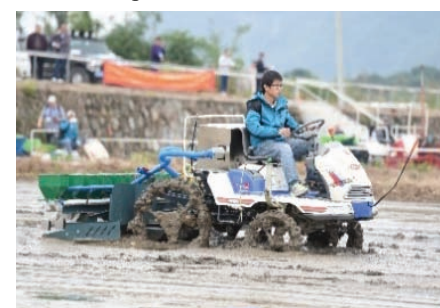

d. PRHDD machine with a vacuum vertical disc

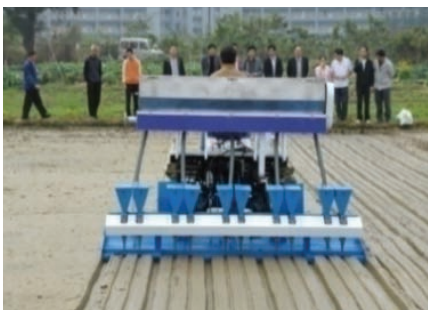

b. PRHDD machine with synchronous side deep fertilizing

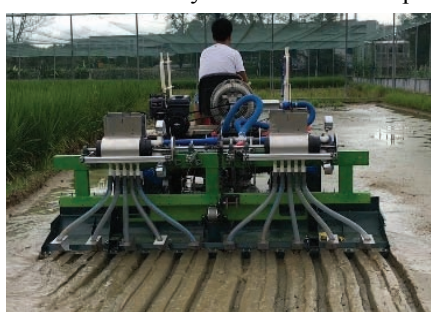

e. PRHDD machine with a vacuum vertical drum

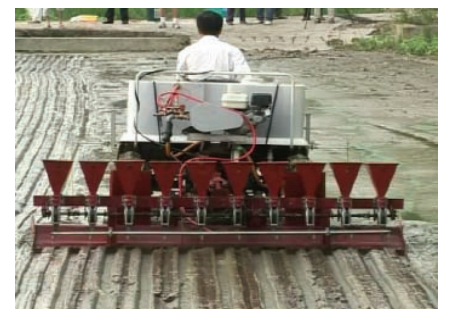

c. PRHDD machine with synchronous spraying

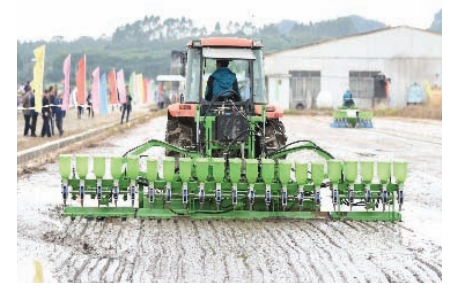

f. Wide PRHDD machine

Figure 15 Different series of hill-drop drilling machine for rice for wet paddy 
Table 1 Main operating parameters of different hill-drop drilling machines for wet paddy

\begin{tabular}{|c|c|c|c|c|c|c|}
\hline No. & Varieties of seeder & $\begin{array}{c}\text { Varieties of metering } \\
\text { device }\end{array}$ & Varieties of rice & $\begin{array}{l}\text { Efficiency ha/h } \\
\text { (Speed } \mathrm{m} / \mathrm{s})\end{array}$ & Seeding bed & $\begin{array}{c}\text { Seeds per hill } \\
\text { (Sowing rate } / \mathrm{kg} / \mathrm{ha} \text { ) }\end{array}$ \\
\hline 1 & Precision direct seeding machine (Kubota) & Roller-type & $\begin{array}{l}\text { Conventional rice } \\
\text { Hybrid rice }\end{array}$ & 1.5 & Surface & $\begin{array}{c}3-15 \\
(30-75 / 75-225)\end{array}$ \\
\hline 2 & Precision rice hill-drop drilling machine & Combined hole-type & $\begin{array}{l}\text { Conventional rice } \\
\text { Hybrid rice }\end{array}$ & 1.5 & Seed furrow & $\begin{array}{c}3-10 / 10-15 \\
(30-75 / 75-225)\end{array}$ \\
\hline 3 & Simple type rice direct-seeder & Combined hole-type & $\begin{array}{l}\text { Conventional rice } \\
\text { Hybrid rice }\end{array}$ & 0.5 & Seed furrow & $\begin{array}{c}3-10 \\
(30-100)\end{array}$ \\
\hline 4 & Vacuum disc rice direct-seeder & Vacuum disc & Hybrid rice & 1 & Seed furrow & $\begin{array}{c}1-3 \\
(15-30)\end{array}$ \\
\hline 5 & Vacuum drum rice direct-seeder & Vacuum drum & Hybrid rice & 1 & Seed furrow & $\begin{array}{c}1-3 \\
(15-30)\end{array}$ \\
\hline 6 & $\begin{array}{l}\text { Synchronous side deep fertilizing with rice } \\
\text { hill-drop drilling machine }\end{array}$ & Combined hole-type & $\begin{array}{l}\text { Conventional rice } \\
\text { Hybrid rice }\end{array}$ & 1.5 & Seed furrow & $\begin{array}{c}3-10 / 10-15 \\
(30-75 / 75-225)\end{array}$ \\
\hline 7 & $\begin{array}{l}\text { Wide precision rice hill-drop drilling } \\
\text { machine }\end{array}$ & Combined hole-type & $\begin{array}{l}\text { Conventional rice } \\
\text { Hybrid rice }\end{array}$ & 1 & Seed furrow & $\begin{array}{c}3-10 / 10-15 \\
(30-75 / 75-225)\end{array}$ \\
\hline
\end{tabular}

\section{Agronomic technical issues in mechanized rice direct seeding}

\subsection{Rice varieties}

Rice varieties used for direct seeding should have the following characteristics. (1) A strong ability to break through the soil for the emergence of seedlings. (2) A strong ability to resist lodging. Crop lodging affects the rice yield and quality, and it is not easy with mechanical harvesting. Studies show that the varieties which plants are shorter, stems are sturdier, and root systems proliferate sufficiently, will have strong lodging resistance $^{[91-93]}$. Most Chinese varieties currently adapt to transplant, and now some varieties with relatively strong lodging resistance and relatively high yield are selected for direct seeding. Therefore, new rice varieties should be bred for direct seeding. Liu et al. ${ }^{[94]}$ reported a new internode dwarf with a rice lodging resistance gene that provided a way to study dwarf varieties suitable for rice direct seeding.

\subsection{Rice seed treatment}

The seedling rate of rice direct seeding can be improved by proper seed treatment ${ }^{[95]}$. The general approach involves seed soaking, pre-germination, and coating ${ }^{[5,16,96-98]}$. Seeds need about $24 \mathrm{~h}$ to general soak and pre-germinate with temperature controlled at about $25^{\circ} \mathrm{C}$. Studies have shown that seed soaking with a certain concentration of salt solutions such as $\mathrm{KCl}, \mathrm{NaCl}$, or $\mathrm{CaCl}_{2}$ is beneficial to rice germination ${ }^{[99-103]}$. Drying can improve the seed germination rate by more than $20 \%$ and reduce the germination time to 1-3 days ${ }^{[16]}$. Japan and South Korea applied iron and calcium oxide coatings and oxidation treatment to seeds to control the precision hill-drop sowing rate. Coated seeds can prevent harm to birds. Furthermore, coated seeds are more than $50 \%$ heavier, and this can prevent drifting in $\operatorname{RWDS}^{[104,105]}$. However, seed coating has a high cost, and it delays germination by $1-3$ days.

The seed treatment of different direct seeding methods is also different. Dry seeding is usually used in rice direct seeding. Dry seeds, wet seeds, or buds can be used with RWDS ${ }^{[16]}$. The coated seeds are treated in different ways and are suitable for various direct seeding methods ${ }^{[5]}$.

\subsection{Chemical weed control in paddy field}

Weeds compete with crops for nutrients, space, sunlight, and water, and affect crop growth and yield. Rice direct seeding was more difficult to control weeds than transplanting, because there is no water layer to control weeds in the field ${ }^{[106]}$, and weeds and rice seeds germinated at almost the same time when direct seeding was performed. An American study transcribed antidrug genes into rice genes to produce strong resistance variety, then targeted chemical herbicides were used to control weeds damage. However, weeds also showed resistance after a few years. In general, early weed control involves deep- ploughing the soil. Deep-ploughing can bury shallow weed seeds deep into the soil; however, it may also turn deep weed seeds to the surface ${ }^{[16]}$. Rotation and intercropping can also be performed and combined with suitable herbicides. Wang ${ }^{[99]}$ conducted a study that spraying Pretilachlor (herbicide) on the third day after sowing, and carried out better weeding effect, little effect on the germination of seeds and the grain yield in Southern China.

\section{Application of precision rice water direct seeding in China}

6.1 Trends

PRHDD with synchronous furrowing and ridging has been popularized and used in 26 Chinese provinces including in Southern China, Southwest China, Yangtze River region, Northeast China, and Northwest China as well as in Thailand, Laos, Burma, Vietnam, and Italy since 2006. Hill-drop drilling technology can meet rice planting requirements under different temperature conditions and planting habits with suitable sowing density (row/hill spacing and seeding rate) and cultivation technology. With technological development, the use of hill-drop drilling for wet paddy has increased rapidly in China, especially in the middle and lower reaches of the Yangtze River region (e.g., Shanghai, Zhejiang, and Anhui). PRHDD technology is extremely suitable for single-cropping rice because of suitable climatic conditions, suitable growth period, suitable varieties of rice, high level of agricultural mechanization, easy acceptance of planting habits, and management departments. Figure 16 shows the trend of precision rice seeding in China since 2006.

\subsection{Rice production costs}

China has a large rice planting area, and rice planting methods are different in each area. Common rice planting methods currently include mechanical transplanting, mechanical throw-planting, mechanical drilling, mechanical hill-drop drilling, manual transplanting, manual throw-planting, and manual sowing. The proportion of areas with manual transplanting and mechanical transplanting is large. However, considering the labour shortage and high production cost, farmers are increasingly switching to manual sowing and mechanical drilling. In recent years, the area 


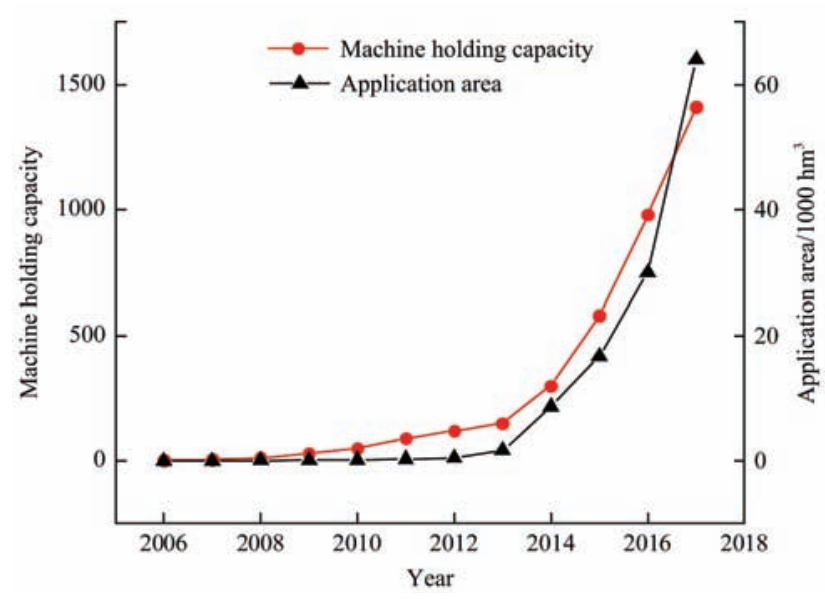

Figure 16 Development trend of machine holding capacity and application area

by mechanized direct seeding has been increasing. PRHDD can be popularized and applied in consideration of its technology feasibility and yield impact as well as its labour intensity and production cost. Therefore, this study identified the advantages of PRHDD from the viewpoint of production efficiency.

(1) Research method

This study investigated the production costs of different rice planting patterns in 15 provinces in China and conducted a comparative analysis of the economic benefits. The rice production cost mainly includes the following aspects: land, tillage, sowing and transplanting (seeding/seedling), agricultural costs (seeds, fertilizers, pesticides, herbicides, etc.), field management, and harvesting.

The total production cost can be calculated as total production cost: $\mathrm{C}_{\mathrm{n}}=\mathrm{C}_{1}$ (cultivated land) $+\mathrm{C}_{2}$ (sowing) $+\mathrm{C}_{3}$ (transplanting) + $\mathrm{C}_{4}$ (agricultural costs) $+\mathrm{C}_{5}$ (harvesting) $+\mathrm{C}_{6}$ (other costs)

where, the sowing cost is divided into direct seeding $\mathrm{C}_{21}$ and seedling $\mathrm{C}_{22}$, and the agricultural cost is divided into seed $\mathrm{C}_{41}$, fertilizer $\mathrm{C}_{42}$, pesticide $\mathrm{C}_{43}$, and herbicide $\mathrm{C}_{44}$. The lease fee $\mathrm{C}_{0}$ differs greatly across different areas, so it is not considered in the total production cost.

The average production cost and average net income of various types of rice planting methods in China can be calculated from the survey data. The "input-output ratio" is used to compare the economic benefits of different technologies. This ratio expresses the unit production or output for 1 unit of investment. It can be expressed in the form $1: \mathrm{N}$, where the higher the $\mathrm{N}$ value, the greater is the economic benefit.

(2) Economic benefit analysis results of different rice planting methods

Figure 17 shows the comparison results of the economic benefits of different rice planting methods. The input-output ratio $(1: \mathrm{N})$ of different rice planting methods decreases in the order of mechanical PRHDD, mechanical drilling, manual seeding, mechanical transplanting, and manual throw-planting. Compared with manual transplanting, manual throw-planting, manual seeding, mechanical transplanting, and mechanical drilling, the average net income of mechanized rice planting is higher by $80 \%, 46.6 \%, 36 \%$, $18.1 \%$, and $6.1 \%$, respectively. Rice direct seeding thus clearly affords a large economic benefit.

\subsection{Rice yield}

Rice yield is an important technical index for evaluating advanced rice planting technologies. Table 2 shows production records for various areas in China. PRHDD showed rice yield exceeding $9 \mathrm{t} / \mathrm{hm}^{2}$, whereas the conventional rice yield was about $8 \mathrm{t} / \mathrm{hm}^{2}$. Compared with manual sowing in the same area, the average yield was increased by $16.7 \%$. The overall average rice yield of PRHDD technology was up to $8.8 \mathrm{t} / \mathrm{hm}^{2}$, which exceeded China's average rice production level of $6.4 \mathrm{t} / \mathrm{hm}^{2}$ (National Statistical Bureau, 2013-2016). Therefore, application of RWDS technology in suitable areas can result in stable and high yields of rice.

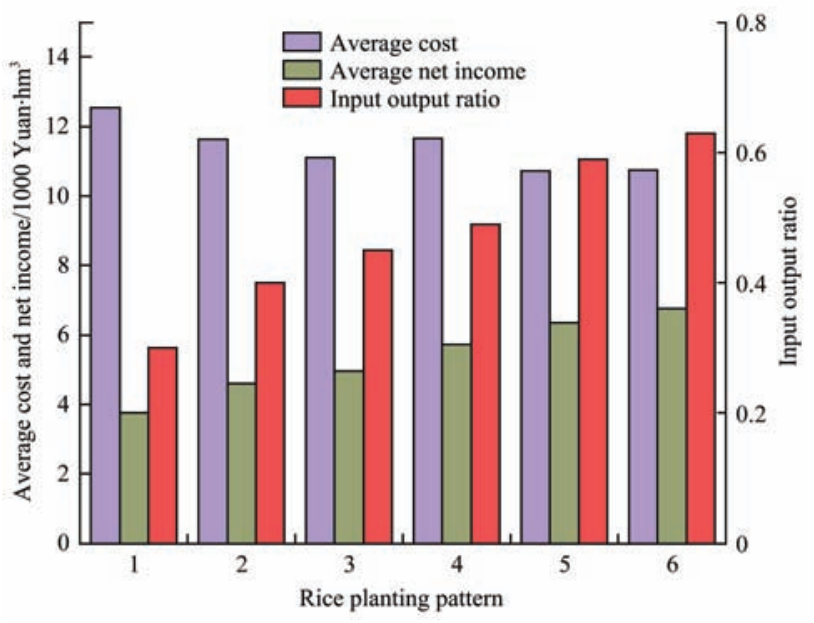

Note: In x axis, 1-6 respectively indicate Manual transplanting, Manual seedling throwing, Manual broadcasting, Mechanical transplanting, Mechanical line sowing, Mechanical hill-drop drilling.

Figure 17 Economic benefits of different rice planting patterns

Table 2 Rice yield of rice hill-drop drilling machine in some regions of China

\begin{tabular}{|c|c|c|c|}
\hline Province & Year & Rice varieties & Yield $/ \mathrm{t} \cdot \mathrm{hm}^{-2}$ \\
\hline Xinjiang & 2015 & Xindao36\# & 10.5 \\
\hline \multirow{2}{*}{ Heilongjiang } & 2015 & Longdao5 & 9.2 \\
\hline & 2017 & Longjing21 & 9.2 \\
\hline \multirow{2}{*}{ Shanxi } & 2014 & Huanghuazhan & 10.7 \\
\hline & 2015 & Huanghuazhan & 12.2 \\
\hline \multirow{8}{*}{ Sichuan } & \multirow{2}{*}{2014} & Dexiang4103 & 9.6 \\
\hline & & Huanghuazhan & 9.5 \\
\hline & \multirow{5}{*}{2015} & Jing3You177 & 11.8 \\
\hline & & Huanghuazhan & 11.5 \\
\hline & & Chuanyou6203 & 9.5 \\
\hline & & Jingyou127 & 10.1 \\
\hline & & Jingnei5You37 & 9.6 \\
\hline & 2017 & Quanyouhuazhan & 12.5 \\
\hline \multirow{3}{*}{ Zhejiang } & 2013 & Chunyou84 & 12.3 \\
\hline & 2014 & Chunyou 84 & 12.5 \\
\hline & 2015 & Chunyou 927 & 12.9 \\
\hline \multirow{3}{*}{ Shanghai } & 2013 & Xiushui134 & 9.4 \\
\hline & 2014 & Xiushui134 & 9.5 \\
\hline & 2015 & Huayou14 & 12 \\
\hline \multirow{3}{*}{ Jiangxi } & 2014 & Zhongjiazao17 & 8.7 \\
\hline & 2015 & Zhuliangyou819 & 8.4 \\
\hline & 2016 & Heshengliangyou1\# & 8.3 \\
\hline
\end{tabular}

\section{Conclusions and prospects}

\subsection{Conclusions}

Compared with other mechanized rice planting techniques, PRHDD with synchronous furrowing and ridging affords obvious advantages and conforms to the scientific concept of combining 
agricultural machinery and agronomy. It affords significant advantages in terms of rice yield, economic benefit, and resource saving by saving time, labour, and cost and increasing efficiency. PRHDD with synchronous furrowing and ridging is therefore being used increasingly in China, and it finds broad application prospects owing to the Chinese government's policy of promoting the development of mechanized rice planting.

\subsection{Prospects}

(1) Natural conditions and cropping systems differ greatly between China and the rest of the world. Therefore, when adopting advanced foreign technologies, direct seeding equipment tailored to Chinese conditions should be developed to achieve increased mechanization of rice direct seeding. PRHDD with synchronous furrowing and ridging technology is a scientific planting mode that has been verified to be compatible with the basic conditions in China.

(2) The rapider development, wider application scale and scope of precision rice hill-drop drilling technology and equipment has attracted more and more agricultural machinery manufacturing companies' (Kubota, Yanmar etc) interest. For example, in China, $30 \%$ of the rice planting area is expected to adopt mechanized direct seeding, which indicates the wide application prospect of precision rice hill-drop drilling technology.

(3) More attention should be paid on the key technologies of the precision rice hill-drop drilling technology, including the metering device and the overall structure of machine. The metering device should be able to adapt to the sowing rate requirements of different rice varieties and maintain accuracy at high speed. The light-weight overall structure and automatic control system (including automatic profiling, seeding quality monitoring) should be designed.

(4) The emphasis of popularization and application of precision rice hill-drop drilling technology is, the combination of agricultural machinery and agronomy, including safe and efficient weeds control, seedling rate protection measures, high yield and quality measures, and so on.

\section{Acknowledgements}

The authors wish to acknowledge the funding from National Postdoctoral Program for Innovative Talents (BX201700083), Introduction of the International Advanced Agricultural Science and Technology Program (948 plan) (Project No.2016-X24), Commonweal Project (Project No. 201203059), 13th Five-year Plan National Key Research Program (Project No. 2017YFD0700503-2). We also thank the anonymous reviewers for their critical comments and suggestions for improving the manuscript.

\section{[References]}

[1] FAO-Food and Agriculture Organization. FAOSTAT Database. FAO, Rome, 2017; http://www.fao.org/faostat/en/\#data/QC. Accessed on [2018-01-20]

[2] Qian L. Off-farm employment, land transfer and changes in agricultural problem. Doctoral dissertation. Hangzhou: Zhejiang University, Dec., 2016; 119p. (in Chinese)

[3] Knight J, Deng Q, Li S. The puzzle of migrant labor shortage and rural labor surplus in China. China Economic Review, 2011; 22(4): 585-600.

[4] Kumar V, Ladha J K. Direct seeding of rice: recent developments and future research needs. Advances in Agronomy. Academic Press, 2011, 111: 297-413.

[5] Yamauchi M. A review of iron-coating technology to stabilize rice direct seeding onto puddled soil. Agronomy Journal, 2017; 109(3): 739-750.

[6] Yan J, Yu J, Tao G C, Vos J, Bouman B A M, Xie G H, et al. Yield formation and tillering dynamics of direct-seeded rice in flooded and nonflooded soils in the Huai River Basin of China. Field Crops Research, 2010; 116(3): 252-259.

[7] Chauhan B S, Awan T H, Abugho S B, Evengelista G. Effect of crop establishment methods and weed control treatments on weed management, and rice yield. Field Crops Research, 2015; 172: 72-84.

[8] Datta D. Principles and practices of rice production. Int. Rice Res. Inst., 1981.

[9] Hill J E, Bayer D E, Bocchi S, Clampett W S. Direct seeded rice in the temperate climates of Australia, Italy, and the United States. Direct Seeded Flooded Rice in the Tropics: Selected Papers from the International Rice Research Conference, 27-31, August 1990, Seoul, Korea. Int. Rice Res. Inst., 1991: 91.

[10] Blanche B, Harrell D, Saichuk J. General agronomic guidelines. Siachuk, ed. Louisiana Rice Production Handbook. Baton Rouge, LA: Louisiana State University Agricultural Center. Pub 2321, 2009.

[11] Dong H, Chen Q, Wang W, Peng S, Huang J, Cui K, et al. The growth and yield of a wet-seeded rice-ratoon rice system in central China. Field Crops Research, 2017; 208: 55-59.

[12] Kargbo M B, Pan S, Mo Z, Wang Z M, Luo X W, Tian H, et al. Physiological basis of improved performance of super rice (Oryza sativa) to deep placed fertilizer with precision hill-drilling machine. International Journal of Agriculture and Biology, 2016; 18(4): 797-804.

[13] Guan C Y. Modern Crop Cultivation. Chinese Higher Education Press, Beijing, 2011. (in Chinese).

[14] Bhuiyan S I, Sattar M A, Khan M A K. Improving water use efficiency in rice irrigation through wet-seeding. Irrigation Science, 1995; 16(1): $1-8$.

[15] Joshi E, Kumar D, Lal B, Nepalia V, Gautam P, Vyas A K. Management of direct seeded rice for enhanced resource-use efficiency. Plant Knowledge Journal, 2013; 2(3): 119.

[16] Farooq M, Siddique K H M, Rehman H, Aziz T, Lee D J, Wahid A. Rice direct seeding: experiences, challenges and opportunities. Soil and Tillage Research, 2011; 111(2): 87-98.

[17] Chhapekar S, Raghavendrarao S, Pavan G, Ramakrishna C, Singh V K, Phanindra M L V, et al. Transgenic rice expressing a codon-modified synthetic CP4-EPSPS confers tolerance to broad-spectrum herbicide, glyphosate. Plant Cell Reports, 2015; 34(5): 721-731.

[18] Humphreys E, Kukal S S, Gill G, Rangarajan R. Effect of water management on dry seeded and puddled transplanted rice: Part 2: Water balance and water productivity. Field Crops Research, 2011; 120(1): $123-132$.

[19] Dawe D. Increasing water productivity in rice-based systems in Asia-past trends, current problems, and future prospects. Plant Production Science, 2005; 8(3): 221-230.

[20] Ahmad S, Li C F, Dai G Z, Zhan M, Wang J P, Pan S G, et al. Greenhouse gas emission from direct seeding paddy field under different rice tillage systems in central China. Soil and Tillage Research, 2009; 106(1): 54-61.

[21] Liu S, Zhang Y, Lin F, Zhang L, Zou, J. Methane and nitrous oxide emissions from direct-seeded and seedling-transplanted rice paddies in southeast China. Plant and Soil, 2014; 374(1-2): 285-297.

[22] Simmonds M B, Anders M, Adviento-Borbe M A, Kessel C V, McClung A, Linquist B A. Seasonal methane and nitrous oxide emissions of several rice cultivars in direct-seeded systems. Journal of Environmental Quality, 2015; 44(1): 103-114.

[23] Gupta D K, Bhatia A, Kumar A, Das T K, Jain N, Tomer R, et al. Mitigation of greenhouse gas emission from rice-wheat system of the Indo-Gangetic plains: Through tillage, irrigation and fertilizer management. Agriculture, Ecosystems \& Environment, 2016; 230: 1-9.

[24] Mahajan G, Chauhan B S, Gill M S. Dry-seeded rice culture in Punjab State of India: lessons learned from farmers. Field Crops Research, 2013; 144: 89-99.

[25] Jat R K, Sapkota T B, Singh R G, Jat M L, Kumar M, Gupta R K. Seven years of conservation agriculture in a rice-wheat rotation of Eastern Gangetic Plains of South Asia: yield trends and economic profitability. Field Crops Research, 2014; 164: 199-210.

[26] Mishra A K, Khanal A R, Pede V O. Is direct seeded rice a boon for economic performance? Empirical evidence from India. Food Policy, 2017; 73: 10-18.

[27] Luo X W, Liao J, Zang Y, Zhou Z Y. Improving agricultural mechanization level to promote agricultural sustainable development. Transactions of the CSAE, 2016; 32(1): 1-11. (in Chinese) 
[28] Rao A N, Brainard D C, Kumar V, Ladha J K, Johnson D E. Preventive weed management in direct-seeded rice: Targeting the weed seedbank. Advances in Agronomy, 2017; 144: 45-142.

[29] Bhushan L, Ladha J K, Gupta R K, Singh S, Tirol-Padre A, Saharawat Y S. Saving of water and labor in a rice-wheat system with no-tillage and direct seeding technologies. Agronomy Journal, 2007; 99(5): 1288-1296.

[30] Weerakoon W M W, Mutunayake M M P, Bandara C, Rao A N, Bhandari D C, Ladha J K. Direct-seeded rice culture in Sri Lanka: lessons from farmers. Field Crops Research, 2011; 121(1): 53-63.

[31] Pandey S, Velasco L. Economics of direct seeding in Asia: patterns of adoption and research priorities. Los Baños (Philippines): International Rice Research Institute. 2002; pp.3-14

[32] Pandey S, Velasco L. Trends in crop establishment methods in Asia and research issues. Rice is life: Scientific perspectives for the 21 st century, $2005 ; 178-181$

[33] Wang D, Chen S, Wang Z M, Ji C L, Xu C M, Zhang X F. Optimizing hill seeding density for high-yielding hybrid rice in a single rice cropping system in South China. PloS One, 2014; 9(10): e109417.

[34] Pan S G, Wen X C, Wang Z M, Ashraf U, Tian H, Duan M Y, Mo Z W, Fan P S, Tang X R. Benefits of mechanized deep placement of nitrogen fertilizer in direct-seeded rice in South China. Field Crops Research, 2017; 203: 139-149.

[35] Espe M B, Cassman K G, Yang H S, Guipart N, Grassini P, Wart J V, Anders M, Beighley D, Harrell D, Linscombe S, McKenzie K, Mutters R, Wilson L T, .Linquist B A. Yield gap analysis of US rice production systems shows opportunities for improvement. Field Crops Research, 2016; 196: 276-283.

[36] Pratley J E, Flower R, Heylin E, Sivapalan, S. Integrated weed management strategies for the rice weeds Cyperus difformis and Alisma plantagoaquatica. A report for the Rural Industries Research and Development Corporation (RIRDC) Project No USC A, 2004; 20.

[37] Bacenetti J, Fusi A, Negri M, Bocchi S, Fiala M. Organic production systems: Sustainability assessment of rice in Italy. Agriculture, Ecosystems \& Environment, 2016; 225: 33-44.

[38] Blengini G A, Busto M. The life cycle of rice: LCA of alternative agri-food chain management systems in Vercelli (Italy). Journal of Environmental Management, 2009; 90(3): 1512-1522.

[39] Park K H. Rice Cultivation Technology in Italy. Journal of the Korean Society of International Agriculture, 2006; 16(4): 325-333. (in Korean)

[40] Li Y M, Xu L Z, Xiang Z P, Deng L L. Research advances of rice planting mechanization in Japan. Transactions of the CSAE, 2005; 21(11): 182-185. (in Chinese)

[41] Ministry of Agriculture, Forestry, and Fisheries, Japan. 2014. Present status of rice direct seeding culture. (In Japanese.) Ministry of Agriculture., Forestry, and Fisheries, Japan. http://www.maff.go.jp/j/seisan/ryutu/ zikamaki/z_genzyo/attach/pdf/index-3.pdf

[42] Dingkuhn M, Schnier H F, De Datta S K, Dorffling K, Javellana C. Relationships between ripening-phase productivity and crop duration, canopy photosynthesis and senescence in transplanted and direct-seeded lowland rice. Field Crops Research, 1991; 26(3-4): 327-345.

[43] Heu H, Kim Y. Analysis of physiological and ecological characteristics of rice cultivated with direct seeding on dry paddy field. Japanese Journal of Crop Science, 1997; 66(3): 442-448. (in Japanese)

[44] San-Oh Y, Mano Y, Ookawa T, Hirasawa T. Comparison of dry matter production and associated characteristics between direct-sown and transplanted rice plants in a submerged paddy field and relationships to planting patterns. Field Crops Research, 2004; 87(1): 43-58.

[45] Yoshinaga S. Improved lodging resistance in rice (Oryza sativa L.) cultivated by submerged direct seeding using a newly developed hill seeder. Japan Agricultural Research Quarterly: JARQ, 2005, 39(3): 147-152. (in Japanese)

[46] Won J G, Lee W H, Choi C D, Kim C R, Choi B S. Growth characteristics and yield of hill-seeded rice in direct seeding. RDA Journal of Agricultural Science (Korea Republic), 1996; 38(1): 49-55. (in Korean)

[47] Yang W H, Kim J K, Lee M H, Chen S C, Han H S. Status and Prospect on Rice Direct Seeding Technology of Farmers. The Journal of the Korean Society of International Agriculture, 2015; 27(3): 342-347. (in Korean)

[48] Ministry of Agriculture of China. The yearbook of agricultural mechanization in China, 2016; 146p. (in Chinese)

[49] Balasubramanian V, Hill J E. Direct seeding of rice in Asia: emerging issues and strategic research needs for the 21 st century. Direct seeding:
Research strategies and opportunities, 2002: 15-39.

[50] Chauhan B S. Management strategies for weedy rice in Asia. Int. Rice Res. Inst., Philippines, 2013.

[51] Tuong T P, Pablico P P, Yamauchi M, Confesor R. Increasing water productivity and weed suppression of wet seeded rice: effect of water management and rice genotypes. Experimental Agriculture, 2000; 36(1): 71-89.

[52] Cassman K G. Ecological intensification of cereal production systems: yield potential, soil quality, and precision agriculture. Proceedings of the National Academy of Sciences, 1999; 96(11): 5952-5959.

[53] Zhang N Q, Wang M H, Wang N. Precision agriculture-a worldwide overview. Computers and electronics in agriculture, 2002; 36(2-3): 113-132.

[54] Jat M L, Gathala M K, Ladha J K, Saharawat Y S, Jat A S, Kumar V, Sharma S K, Kumar V, Gupta R. Evaluation of precision land leveling and double zero-till systems in the rice-wheat rotation: Water use, productivity, profitability and soil physical properties. Soil and Tillage Research, 2009; 105(1): 112-121.

[55] EI-Kader S M A, EI-Basioni B M M. Precision farming solution in Egypt using the wireless sensor network technology. Egyptian Informatics Journal, 2013; 14(3): 221-233.

[56] Ryu I H, Kim K U. Design of roller type metering device for precision planting. Transactions of the ASAE, 1998; 41(4): 923.

[57] Maleki M R, Jafari J F, Raufat M H, Mouazen A M, Baerdemaeker J D. Evaluation of seed distribution uniformity of a multi-flight auger as a grain drill metering device. Biosystems Engineering, 2006; 94(4): 535-543.

[58] Maleki M R, Mouazen A M, De Ketelaere B, De Baerdemaeker, J. A New Index for Seed Distribution Uniformity Evaluation of Grain Drills. Biosystems Engineering, 2006; 94(3): 471-475.

[59] AMAZONEN-Werke H. Dreyer FmbH \& Co. KG, 2017. http://www.amazone.net/96.asp

[60] AMAZONEN-Werke H. Dreyer FmbH \& Co. KG, 2017. http://www.amazone.net/97.asp

[61] Yoo S N, Choi Y S, Suh S R. Development of a precision seed metering device for direct seeding of rice. Journal of Biosystems Engineering, 2005; 30(5): 261-267. (in Korean)

[62] Togashi T, Shimotsubo K, Yoshinaga S. Development of seed-shooting seeder of rice combined with a paddy harrow and characteristics of the sowing depth. Japanese Journal of Farm Work Research, 2001; 36(4): 179-186. (in Japanese)

[63] Tasaka K, Yoshinaga S, Matsushima K, Wakimoto K. Studies on the improvement of the hill seeding shape of shooting hill-seeder of rice combined with a paddy harrow. Journal of the Japanese Society of Agricultural Machinery, 2003; 65(1): 167-176.

[64] Zhang S, Xia J f, Zhou Y, Zhai J B, Guo Y M, Zhang X M, Wu H. Design and experiment of pneumatic cylinder-type precision direct seed-metering device for rice. Transactions of the CSAE, 2015; 31(1): 11-19. (in Chinese)

[65] Zhang G Z, Zhang S S, Yang W P, Lu K, Lei Z Q, Yang M. Design and experiment of double cavity side-filled precision hole seed metering device for rice. Transactions of the CSAE, 2016; 32(8): 9-17. (in Chinese)

[66] Chen X G, Lu Y T. Sowing-performance of Air-suction Cylindrical Cotton Precision Dibble. Transactions of the CSAM, 2010; 41(8): 35-38. (in Chinese)

[67] Chen X G, Zhong L M. Design and test on belt-type seed delivery of air-suction metering device. Transactions of the CSAE, 2012; 28(22): 8-15. (in Chinese)

[68] Zhang M H, Luo X W, Wang Z M, Dai Y Z, Wang B L, Zheng L. Design and experiment of combined hole-type metering device of rice hill-drop drilling machine. Transactions of the CSAM, 2016; 47(9): 29-36. (in Chinese)

[69] Xing H, Zang Y, Wang Z M, Luo X W, Zhang G Z, Cao X M, et al. Design and experiment of stratified seed-filling room on rice pneumatic metering device. Transactions of the CSAE, 2015; 31(4): 42-48. (in Chinese)

[70] Zang Y, Xing H, Wang Z M, Luo X W, Cao X M, Wang B L. Design and experiment of shield device on rice pneumatic metering device. Transactions of the CSAM, 2015; 46(5): 33-38. (in Chinese)

[71] Zhang G Z, Luo X W, Zang Y, Wang Z M, Zeng S, Zhou Z Y. Experiment of sucking precision of sucking plate with group holes on rice pneumatic metering device. Transactions of the CSAE, 2013; 29(6): 13-20. (in Chinese)

[72] Kajitani K. No-till rice planting and its direct seeder. Journal of the 
Japanese Society of Agricultural Machinery, 1996; 58(6): 145-147. (in Japanese)

[73] Yashiro M. New technology for the direct sowing of rice on dry field. Journal of the Japanese Society of Agricultural Machinery, 1997; 59(3): 133-137. (in Japanese)

[74] Nishimura Y, Hayashi K, Gotoh T, Horio M, Ichikawa T, Ueda Y. Development of a precision direct drill seeder for direct sowing of rice on paddy field (Part 1). Journal of the Japanese Society of Agricultural Machinery, 2001; 63(6): 107-113. (in Japanese)

[75] Nishimura Y, Hayashi K, Gotoh T, Horio M, Ichikawa T, Asano S, et al. Development of a precision direct drill seeder for direct sowing of rice on paddy field (Part 2). Journal of the Japanese Society of Agricultural Machinery, 2001; 63(6): 114-121. (in Japanese)

[76] Nishimura Y, Hayashi K, Gotoh T, Horio M, Ichikawa T, Asano S, et al. Development of a Precision Direct Drill Seeder for Direct Sowing of Rice on Paddy Field (Part 3). Journal of the Japanese Society of Agricultural Machinery, 2001; 63(6): 122-130. (in Japanese)

[77] Nishimura Y, Hayashi K, Gotoh T, Horio M, Ichikawa T. Development of a Precision Direct Drill Seeder for Direct Sowing of Rice on Paddy Field (Part 4). Journal of the Japanese Society of Agricultural Machinery, 2003; 65(1): 143-151. (in Japanese)

[78] Chosa T, Furuhata M, Omine M, Matsumura O. Development of air-assisted strip seeding for direct seeding in flooded paddy fields: Seeding machine and effect of air assistance. Farm Work Research: Journal of Farm Work Society of Japan, 2009; 141: 211-218. (in Japanese)

[79] Furuhata M, Chosa T, Shioya Y, Tsukamoto T, Seki M, Hosokawa H. Developing direct seeding cultivation using an air-assisted strip seeder. Japan Agricultural Research Quarterly, 2015; 49(3): 227-233.

[80] Yoo S N, Kim D H, Choi Y S, Suh S R. Development of a precision seeder for direct seeding of rice on dry paddy. Journal of Biosystems Engineering, 2008; 33(2): 83-93. (in Korean)

[81] Cai D L. Manufacturing and Test of Accurate Rice Hill-drop Planter. Master dissertation. Nanjing: Nanjing Agricultural University, Dec., 2011; 35p. (in Chinese)

[82] Tang Y L. Design and Experimental Research on the Rice Direct Seeder. Master dissertation. Hefei: Anhui Agricultural University, June, 2014; 59p. (in Chinese)

[83] Wang Z M, Luo X W, Tang X R, Ma G H, Zhang G Z, Zeng S. Precision Rice Hill Direct Seeding Technology and Machine Based on the Combination of Agricultural Machinery and Agronomic Technology. Journal of South China Agricultural University, 2010; 31(1): 91-95. (in Chinese)

[84] Zhang M H, Wang Z M, Luo X W, Yang W W, Dai Y Z, Wang B L. Design and experiment of furrowing device of precision hill-drop drilling machine for rice. Transactions of the CSAE, 2017; 33(5): 10-15. (in Chinese)

[85] Zhang M H, Luo X W, Wang Z M, Wang B L, Xue Z L. Optimization design and experiment of profiling and slide board mechanism of precision rice hill-drop drilling machine. Transactions of the CSAE, 2017; 33(6): 18-26. (in Chinese)

[86] Zhang M H. Optimal design and experimental research of precision rice hill-drop drilling machine. Doctoral dissertation. Guangzhou: South China Agricultural University, June, 2017; 88p. (in Chinese)

[87] Wang Z M. Design and experiments of precision rice hill-drop drilling technology with synchronous furrowing and ridging. Doctoral dissertation. Guangzhou: South China Agricultural University, June, 2016; 88p. (in Chinese)

[88] Chen X F, Luo X W, Wang Z M, Zhang M H, Hu L, Zeng S, et al.
Experiment of synchronous side deep fertilizing technique with rice hill-drop drilling. Transactions of the CSAE, 2014; 30(16): 1-7. (in Chinese)

[89] Xing H, Wang Z M, Luo X W, Cao X M, Liu C B, Zang Y. General structure design and field experiment of pneumatic rice direct-seeder. Int J Agric \& Biol Eng, 2017; 10(6): 31-42.

[90] Yang W W, Luo X W, Wang Z M, Zhang M H, Zeng S, Zang Y. Design and experiment of track filling assembly mounted on wheeled-tractor for paddy fields. Transactions of the CSAE, 2016; 32(16): 26-31. (in Chinese)

[91] Ishimaru K, Togawa E, Ookawa T, Kashiwagi T, Madoka Y, Hirotsu N. New target for rice lodging resistance and its effect in a typhoon. Planta, 2008; 227(3): 601-609.

[92] Ookawa T, Hobo T, Yano M, Murata K, Ando T, Miura H, et al. New approach for rice improvement using a pleiotropic QTL gene for lodging resistance and yield. Nature communications, 2010; 1: 132.

[93] Zhang J, Li G H, Song Y P, Liu Z H, Yang C D, Tang S, et al. Lodging resistance characteristics of high-yielding rice populations. Field Crops Research, 2014; 161: 64-74.

[94] Liu C, Zheng S, Gui J S, Fu C J, Yu H S, Song D L, et al. Shortened basal internodes encodes a gibberellin 2-oxidase and contributes to lodging resistance in rice. Molecular Plant, 2018; 11(2): 288-299.

[95] Farooq M, Barsa S M A, Wahid A. Priming of field-sown rice seed enhances germination, seedling establishment, allometry and yield. Plant Growth Regulation, 2006; 49(2-3): 285-294.

[96] Farooq M, Basra S M A, Karim H A, Afzal I. Optimization of seed hardening techniques for rice seed invigoration. Emirates Journal of Food and Agriculture, 2004; 16: 48-57.

[97] Farooq M, Basra S M A, Tabassum R, Afzal I. Enhancing the performance of direct seeded fine rice by seed priming. Plant Production Science, 2006; 9(4): 446-456.

[98] Farooq M, Basra S M A, Afzal I, Khaliq A. Optimization of hydropriming techniques for rice seed invigoration. Seed Science and Technology, 2006; 34(2): 507-512.

[99] Farooq M, Basra S M A, Hafeez K. Seed invigoration by osmohardening in coarse and fine rice. Seed Science and Technology, 2006; 34(1): $181-187$.

[100] Hussain S, Khan F, Hussain H A, Nie L. Physiological and biochemical mechanisms of seed priming-induced chilling tolerance in rice cultivars. Frontiers in plant science, 2016; 7: 116.

[101] Jisha K C, Puthur J T. Seed priming with beta-amino butyric acid improves abiotic stress tolerance in rice seedlings. Rice Science, 2016; 23(5): 242-254.

[102] Aloui H, Souguir M, Latique S, Hannachi C. Germination and growth in control and primed seeds of pepper as affected by salt stress. Cercetari agronomice în Moldova, 2014; 47(3): 83-95.

[103] Nouman W, Basra S M A, Yasmeen A, Gull T, Hussain S B, Zubair M, et al. Seed priming improves the emergence potential, growth and antioxidant system of Moringa oleifera under saline conditions. Plant growth regulation, 2014; 73(3): 267-278.

[104] Pehlivan E, Tran T H, Ouédraogo W K I, Schmidt C, Zachmann D, Bahadir M. Removal of As (V) from aqueous solutions by iron coated rice husk. Fuel processing technology, 2013; 106: 511-517.

[105] Yamauchi M. A Review of Iron-Coating Technology to Stabilize Rice Direct Seeding onto Puddled Soil. Agronomy Journal, 2017; 109(3): 739-750.

[106] Thakur A K, Roychowdhury S, Kundu D K, Singh R. Evaluation of planting methods in irrigated rice. Archives of Agronomy and Soil Science, 2004; 50(6): 631-640. 